\title{
Estimation of Sea Level Rise in Santos Port (Brazil)
}

\author{
P. Alfredini \& E. Arasaki \\ Sao Paulo University, São Paulo, Brazil
}

\begin{abstract}
Santos Port is located in São Paulo State Coast (Brazil), in an estuarine area inside Santos Bay named Baixada Santista. The currents behavior is forced by tides. The resulting tidal level variability (high tide, mean sea level and low tide) recorded from Santos Dock Company tide gauge (1940 to 2014), the longest series of continuous record of tides in Brazil, shows a consistent increasing trend. The estimation about the magnitude of mean sea level rise (MSLR) in recommendations, guidelines or requirements issued by different countries and agencies from 1990 provide examples of different approaches used around the world in comparison with the local trends obtained for Santos Port. It is concluded that MSLR will have a considerable impact upon the port, with approximately $1.0 \mathrm{~m}$ rise estimated from 1990 to 2100 . Baixada Santista is a lowland situated a few meters upper from the sea level and some areas are possible to be submerged in the end of this century. Other two locations in São Paulo State Coast, Cananeia and Ubatuba, respectively to the SE and NW of Santos, were also compared with the port tidal data to evaluate the consistency of the trends.
\end{abstract}

\section{INTRODUCTION}

According to Nicholls et al. [8], port cities are a vital component of the global economy and are increasingly becoming important concentrations of population and asset value. Thirteen out of the twenty most populated cities in the world in 2005 were port cities.

Sea level rise (SLR) and the increasing occurrence of stronger storm surge events in metropolitan regions of ports cities with more than one million inhabitants in 2005 were analyzed by Nicholls et al. [8] and ranked according to exposed population and assets in 2005 and 2070, including Santos (Brazil).

Santos Port is situated in Santos Estuary, State of São Paulo Coast (Figure 1), is the largest multipurpose port in South America with over than $16 \mathrm{~km}$ of quays. Per year, a throughput of 120 million tons of cargo is made [2].

The estimation about the magnitude of SLR in recommendations, guidelines or requirements issued by different countries and agencies [3] provide examples of different approaches used around the world in comparison with the local trends obtained for Santos Port.

São Paulo State Coast has a linear length of 500 $\mathrm{km}$. Hence, two other locations, Cananeia (200 km SW of Santos) and Ubatuba (150 km NE of Santos), see Figure 1, had their SLR compared with Santos, which is considered the Central Littoral of São Paulo State Coast.

The objective of this paper is to check the similarity of Santos SLR with nearby locations of São 
Paulo State Coast and classify the SLR according international guidelines known.

\section{MATERIAL}

\subsection{Tides and mean sea level (MSL) variability in Santos Port}

Long term sea level observations are useful for many researches as: tidal analyses, tidal modeling, studies of the ocean dynamics and evaluation of greenhouse impacts. Beside these, works on the estimation of the MSL trends and periodicities were developed in the last years in order to estimate the rates of changes of the sea level [4, 7 and 10]. These works, considering different long series of sea level, studied the longterm trends of each location.

\subsection{SLR impacts on port operation and the surrounding neighborhood}

These problems, discussed in [1, 2 and 10], are basically consequences of the reduction of quays freeboard, flooding due to insufficient effectiveness of the present drainage system and the increasing sedimentation in the nautical areas. The increasing in the salinity intrusion upward the estuary due to higher tidal levels will seriously affect the riparian mangroves and will reduce this fine sediment trap. Without this retention, a larger amount of sediment will be carried to the inner nautical areas of Santos Port, silting and increasing the dredging volumes of maintenance.

Make available information on the impacts of climate change on the maritime port environment has become an international issue for ports to address global warming impacts [10].

The exact coordinates of the three tide gauges of this study, according to [5 and 6] are:

- Santos Port: $23^{\circ}$ 57.3' S; $46^{\circ} 18.6^{\prime} \mathrm{W}$

- Cananeia: $25^{\circ} 01.0^{\prime} \mathrm{S} ; 47^{\circ} 55.7^{\prime} \mathrm{W}$
- Ubatuba: $23^{\circ} 28.8^{\prime} \mathrm{S} ; 45^{\circ} 04.9^{\prime} \mathrm{W}$

The tide gauge, which measured water level fluctuations in Santos Port, provided exact four lunar nodal periods (1940 until 2014) of 18.61 years each one. It is the longest series of continuous record of tides in Brazil and shows a consistent increasing trend. This is an important astronomical criterion, because take in account complete cycles of repeatability of the Moon influence on the MSL trend, which estimation make possible to evaluate with reliability if the tidal level shows a MSLR after completed each cycle. For each year was plotted three dots:

- MSL

- HHW (Highest High Water)

- LLW (Lowest Low Water)

The tide gauge of Cananeia belongs to Oceanographic Institute of São Paulo University (IOUSP). Exact two lunar nodal periods (1957 until 1993) were selected [6].

The tide gauge of Ubatuba belonged to Geological and Geographic Institute of São Paulo State (IGC). Exact two lunar nodal periods (1954 until 1991) were selected. This series has many gaps in the recorded tide level, but is the best for the North of São Paulo State Coast. For this reason, it was employed monthly data to increase the statistics evaluation [3].

\section{METHODS}

The Projected SLR resulting from simulations of different climate scenarios since the work undertaken by the IPCC [5] increases from 1986 - 2005 to 2081 2100 in the range from 0.26 to $0.82 \mathrm{~m}$. However, it is evident that a MSLR in the range of 0.40 to $0.63 \mathrm{~m}$, i.e. in the order of $0.50 \mathrm{~m}$ in 2081-2100 is expected as an average of all the modeling results reported in IPCC [7].

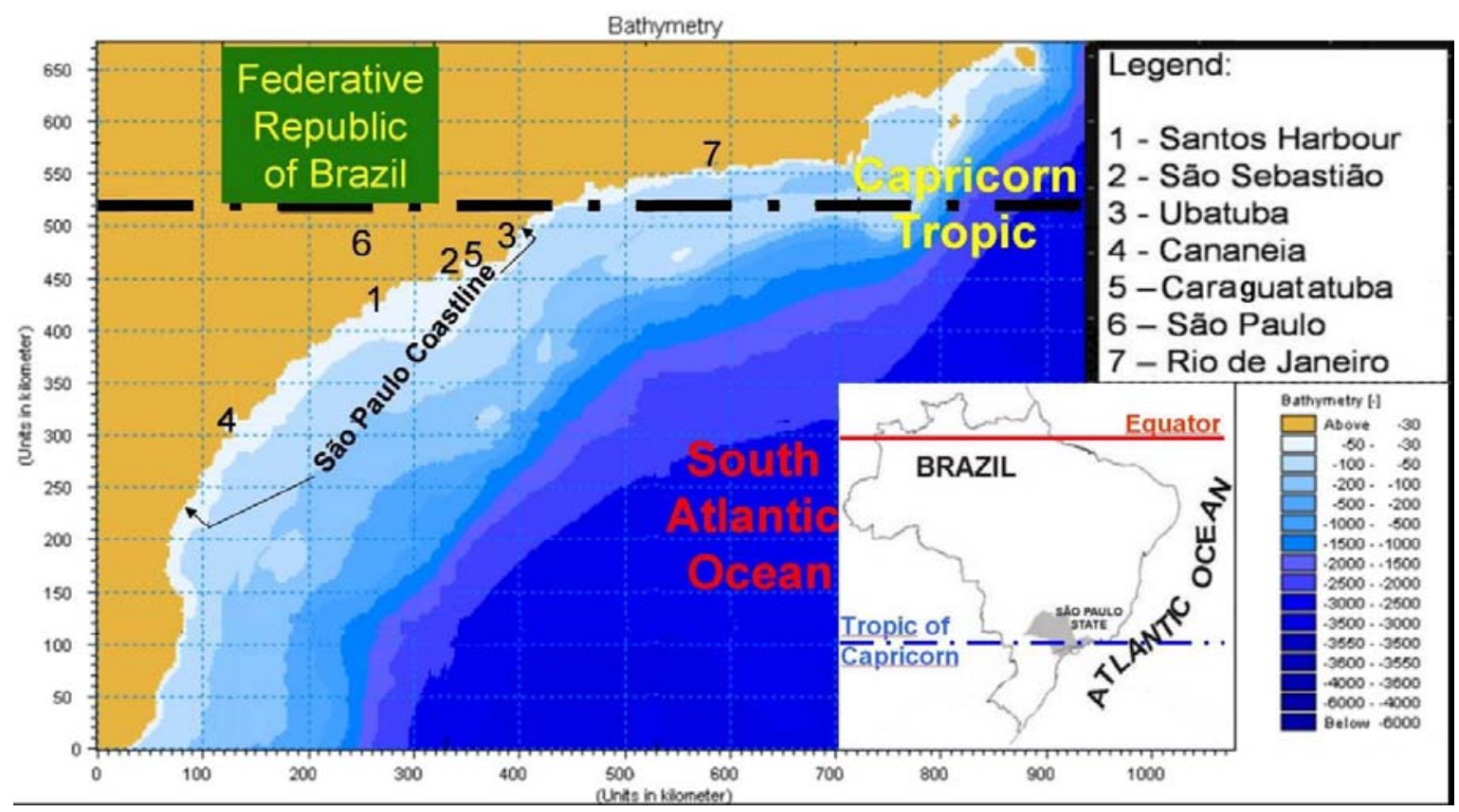

Figure 1. Map of São Paulo State Coast. Location of the study area, showing Santos Port, Cananeia and Ubatuba. 
A likely scenario to use as practical recommendation seems to be that the SLR in year 2100 will be in the range of $0.5 \mathrm{~m}$ to $1.0 \mathrm{~m}$, however with a risk of being about $50 \%$ higher and that the sea level will continue rising also after year 2100, according to Table 1 [9].

There are many approaches for determining an appropriate MSLR scenario, but it is impossible to predict exactly how the future sea level will develop. Consequently, various authorities have developed different estimations [9] as follows.

As example of local practices, the DEFRA Department for Environment, Food \& Rural Affairs of the UK Government [4] in anticipation of increased future SLR, recommend that new engineering projects with a 100-year design life are required to include up to $1 \mathrm{~m}$ of SLR from 1990, recognizing that the rate of rise is expected to be larger at the end of this century than at the beginning of the century (Table 2). Other local practices mentioned by PIANC [3] are the projections of the Delta Commission in The Netherlands (projecting up to 1.4 m MSLR from 1990 to 2100 and for USA: California, Oregon and Washington States (Table 3) from 2000.

Considering the period from 1990 until 2014 as an adjustment period for the calibration of the MSLR rate obtained from the tide gauge of Santos Port, this was compared with the rates of UK [4] (moderate rate), States of California, Washington and Oregon [3], The Netherlands Delta Project (equivalent to Rahmstorf [11], higher rate), PIANC [9] higher and lower rate, IPCC [7] higher and lower rate and Rahmstorf [11] lower rate. From these rates, was adopted the best fit to forecast MSLR rate for Santos Port till 2100.

Table 1. Example of scenario for sea level rise (SLR) as function of type of infrastructure impacted by the design event according to PIANC [3].

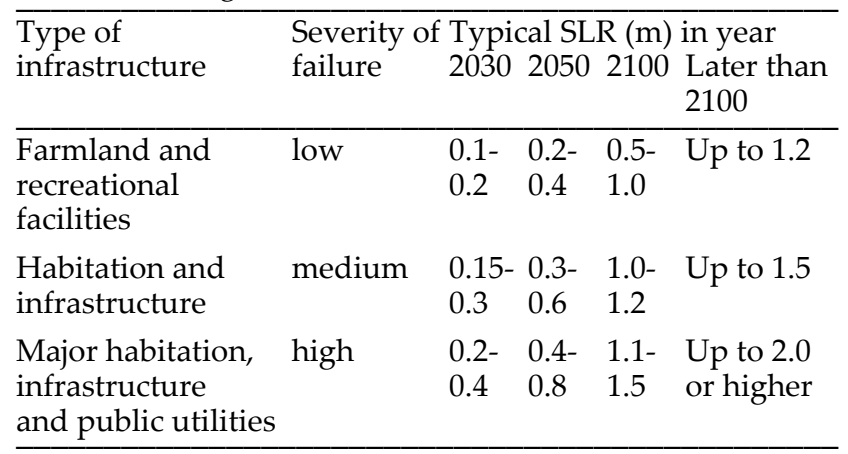

Table 2. UK recommended net SLR rates and cumulative amounts, relative to 1990 [4].

\begin{tabular}{|c|c|c|c|}
\hline $\begin{array}{l}\text { Time } \\
\text { period }\end{array}$ & $\begin{array}{l}\begin{array}{l}\text { Low rate } \\
(\mathrm{mm} / \mathrm{yr}) /\end{array} \\
\text { cumulative } \\
\text { SLR since } \\
1990(\mathrm{~m}) \text { at } \\
\text { end of period }\end{array}$ & $\begin{array}{l}\begin{array}{l}\text { Moderate rate } \\
(\mathrm{mm} / \mathrm{yr}) /\end{array} \\
\text { cumulative } \\
\text { SLR since } \\
1990(\mathrm{~m}) \text { at } \\
\text { end of period }\end{array}$ & $\begin{array}{l}\begin{array}{l}\text { High rate } \\
(\mathrm{mm} / \mathrm{yr}) /\end{array} \\
\text { cumulative } \\
\text { SLR since } \\
1990(\mathrm{~m}) \text { at } \\
\text { end of period }\end{array}$ \\
\hline 1990-2025 & $2.5 / 0.09$ & $3.5 / 0.12$ & $4.0 / 0.14$ \\
\hline 2025-2055 & 7.0/0.30 & $8.0 / 0.36$ & $8.5 / 0.40$ \\
\hline 2055-2085 & $10.0 / 0.60$ & 11.5/0.71 & $12 / 0.75$ \\
\hline 2085-2115 & $13.0 / 0.99$ & $14.5 / 1.14$ & $15 / 1.21$ \\
\hline
\end{tabular}

Table 3. SLR projections relative to year 2000 for Seattle, Newport, San Francisco and Los Angeles [3].

\begin{tabular}{llll}
\hline Cities & $\begin{array}{l}2030 \\
\text { Projection } \\
(\mathrm{cm})\end{array}$ & $\begin{array}{l}2050 \\
\text { Projection } \\
(\mathrm{cm})\end{array}$ & $\begin{array}{l}2100 \\
\text { Projection } \\
(\mathrm{cm})\end{array}$ \\
\hline Seattle & $6.6 \pm 5.6$ & $16.6 \pm 10.5$ & $61.8 \pm 29.3$ \\
Newport & $6.8 \pm 5.6$ & $17.2 \pm 10.3$ & $63.3 \pm 28.3$ \\
San Francisco & $14.4 \pm 5.0$ & $28.0 \pm 9.2$ & $91.9 \pm 25.5$ \\
Los Angeles & $14.7 \pm 5.0$ & $28.4 \pm 9.0$ & $93.1 \pm 24.9$ \\
\hline
\end{tabular}

Finally, the MSLR results from Cananeia and Ubatuba were compared with Santos.

In addition to the MSLR, in each locality the maximum high-tide and the lowest low-tide were plotted considering a linear fit. Obviously, this linear adjustment is not the best ( $\mathrm{R}^{2}$ low), but it gives a tendential gradient of MSLR.

\section{RESULTS}

In the graph of Figure 2 is presented Santos Port annual tidal level variability from 1940 to 2014 and the linear trends of MSL, HHW and LLW. The vertical level employed CDS (Santos Dock Company) datum.

In the graph of Figure 3 is presented the mobile average of 19 years (approximately the lunar nodal period), showing a consistent increasing of the MSL. From 1940 to 2014, the linear gradient of the MSLR was $0.33 \mathrm{~cm} /$ year with a coefficient of determination $\mathrm{R}^{2}=0.4673$, relatively high for this kind of phenomena.

As it is possible to see in Figure 4, the best fit of the calibration for the linear MSLR trend of $0.33 \mathrm{~cm} /$ year was obtained with UK MSLR moderate rate $(0.35$ $\mathrm{cm} /$ year from 1990 to 2014). Hence, the forecasting linear trends for Santos Port were plotted following Table 2 moderate rate from 2014 to 2100 .

The resulting MSLR from 1940 to 2100 shows a consistent increasing trend, indeed, compare the following forecasts for 2100 with reference to 1940:

- $174.8 \mathrm{~cm}$ : PIANC [3] higher rate.

- $156.5 \mathrm{~cm}$ : The Netherlands (Rahmstorf, [11], higher rate).

- $134.8 \mathrm{~cm}$ : PIANC [9] lower rate.

- $112.3 \mathrm{~cm}$ : California State.

- $108.9 \mathrm{~cm}$ : linear trend of the record of the tide gauge of Santos Port from 1940 to 2014 and adjusted from 2014 with UK [4] moderate rate.

- $108.3 \mathrm{~cm}$ : IPCC [7] higher rate.

- $82.4 \mathrm{~cm}$ : Oregon and Washington States.

- $54.5 \mathrm{~cm}$ : Rahmstorf [11] lower rate.

- $47.0 \mathrm{~cm}$ : IPCC [7] lower rate.

- $108.9 \mathrm{~cm}$ : Average value of the mentioned nine

MSLR estimations from 1940 to 2100 . It is exactly equal for Santos Port MSLR rate proposed in this paper.

MSLR for the other locations resulted in:

- Cananeia: $0.38 \mathrm{~cm} /$ year with $\mathrm{R}^{2}=0.5795$ (Figure 5). The vertical level employed IOUSP datum.

- Ubatuba: $0.23 \mathrm{~cm} /$ year with $\mathrm{R}^{2}=0.1412$ (Figure 6). The vertical level employed IGC datum. 
The average MSLR between the two locations is $0,31 \mathrm{~cm} /$ year.

\section{DISCUSSION}

MSLR trend of Santos Port tide gauge from 1990 to 2014 was compared with the recommended rates of UK [11] (moderate rate), States of California, Washington and Oregon [9], The Netherlands Delta Project (equivalent to [11] higher rate), [9] higher and lower rate, [7] higher and lower rate and [11] lower rate. The best adjustment occurred with UK recommended rate [4] (moderate rate), but also California State and [9] higher rates are quite similar. The average MSLR from 1940 to 2100 from all the mentioned methods is identical of Santos Port projection to 2100 using UK [4] (moderate rate). This is an important result, and also showing consistence with the $0.31 \mathrm{~cm} /$ year, average MSLR of the other two locations of São Paulo State Coast, very close to 0.33 $\mathrm{cm} /$ year, estimated for Santos Port.
The linear trends rates for HHW and LLW are rather more disperse, but all of them pointing for a tide level rise. This pattern of dispersion was expected, because of the randomic effect of meteorological tides.

\section{CONCLUSIONS}

The assessment of MSLR in Santos Port shows a reliable consistence in comparison with several international recommendations and also with similar trends in other two locations of São Paulo State Coast , giving confidence to its use for estimative impacts due to the maritime consequences of climate changes. The estimative of MSLR from 1940 to 2100 is $1.1 \mathrm{~m}$, following from 1940 to 2014 a rate of $0.33 \mathrm{~cm} /$ year, which should increase in the next decades in a similar trend of UK recommendations for a moderate scenario.

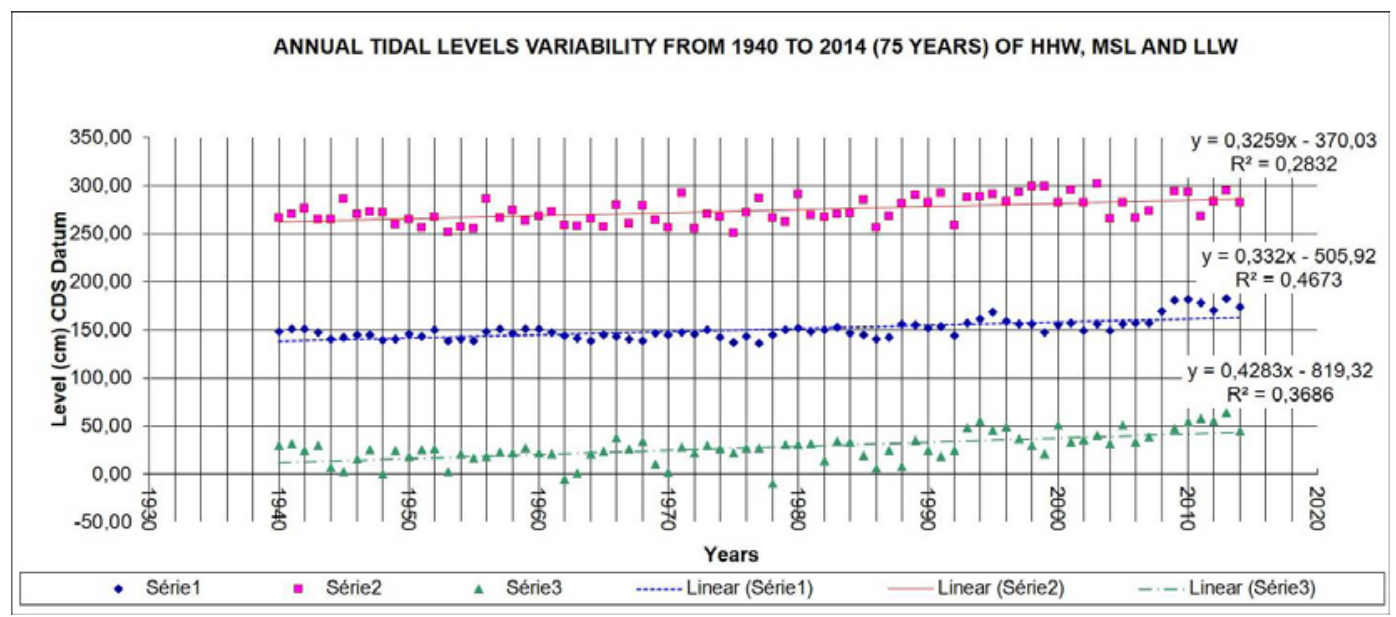

Figure 2. Graph of Santos Port annual tidal level variability from 1940 to 2014. Linear trends of MSL (Mean Sea Level), HHW (Highest High Water) and LLW (Lowest Low Water).

\section{YEARS MOBILE AVERAGE OF HHW, MSL AND LLW} Level $(\mathrm{cm})$ CDS Datum x Years

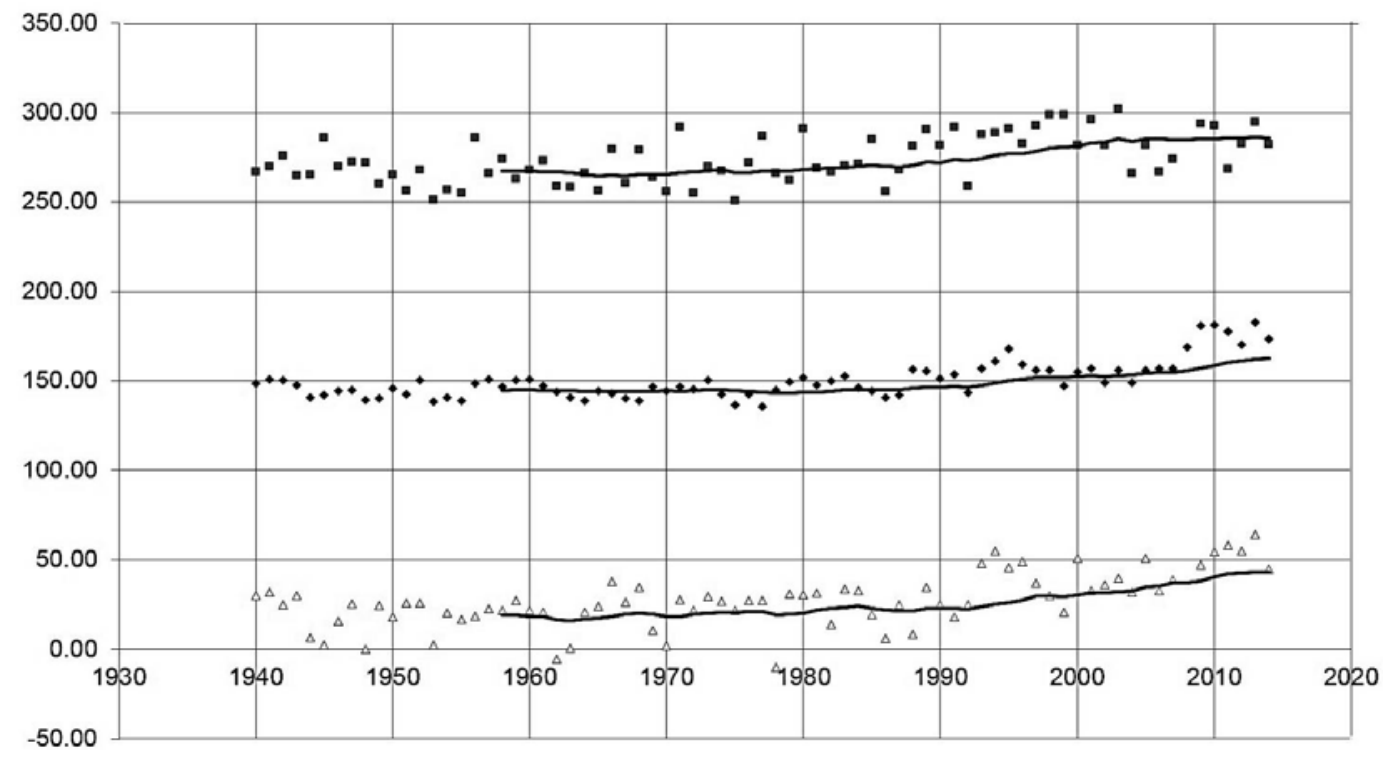

Figure 3. Graph of tide mobile average of 19 years for MSL, HHW and LLW in Santos Port. It is possible to observe a consistent SLR of the levels from 1990. 


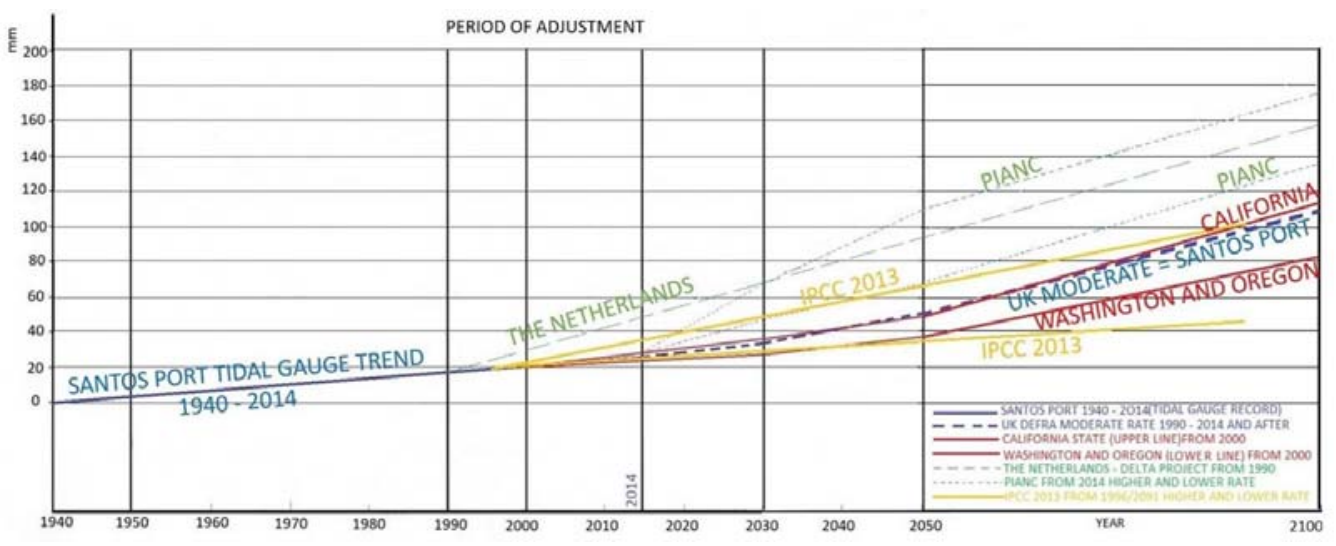

Figure 4. Graph of Santos Port MSL linear trend from 1940 to 2014, with the period of adjustment (1990 to 2014 ) for the selection of the best fit among some of the most known proposed international recommendations. Projection from 1990 to 2100 for Santos Port MSL trend adjusted and comparisons with the international guidelines.

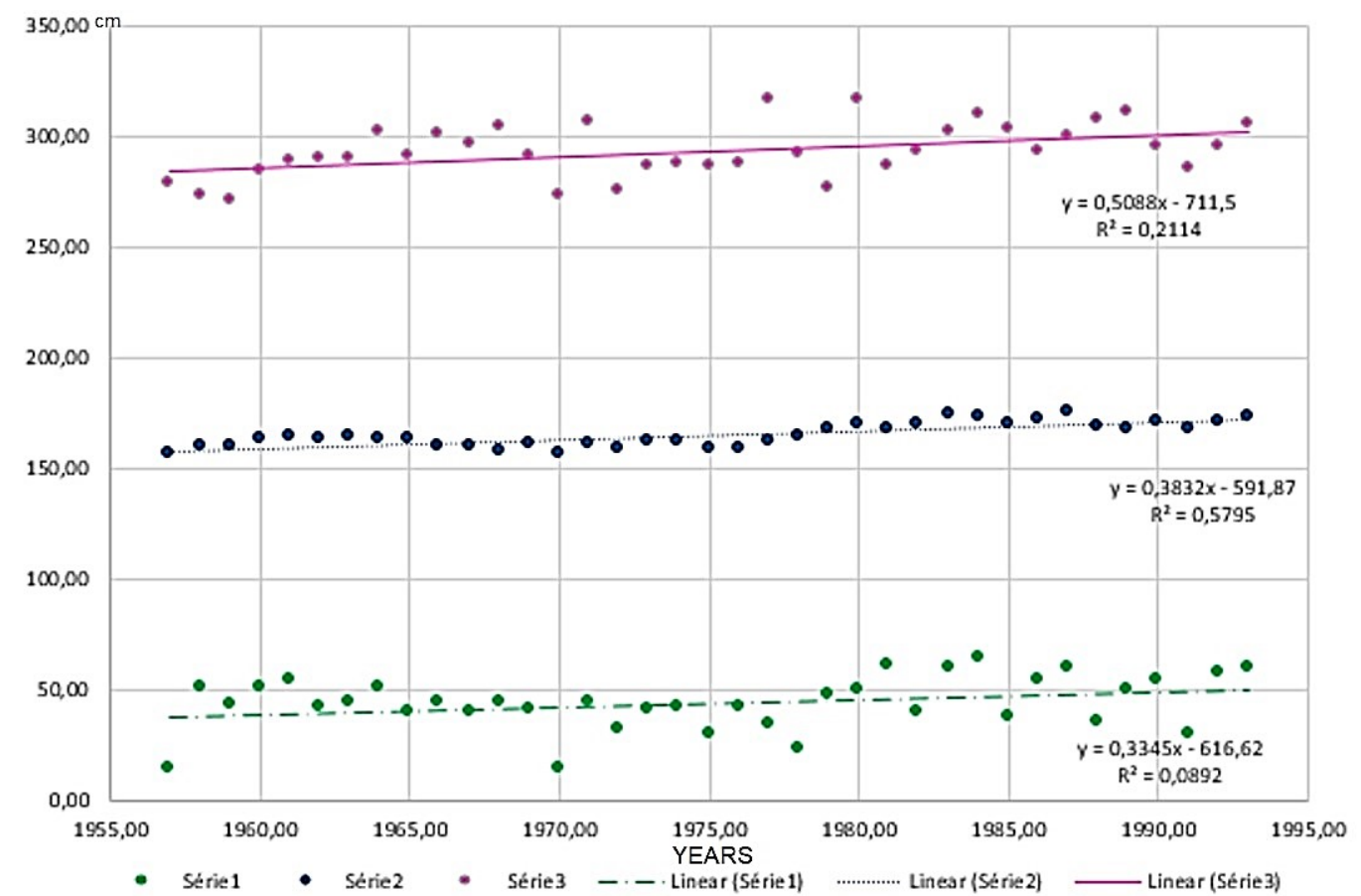

Figure 5. Graph of Cananeia annual tidal level variability from 1957 to 1993. Linear trends of MSL (Mean Sea Level), HHW (Highest High Water) and LLW (Lowest Low Water).

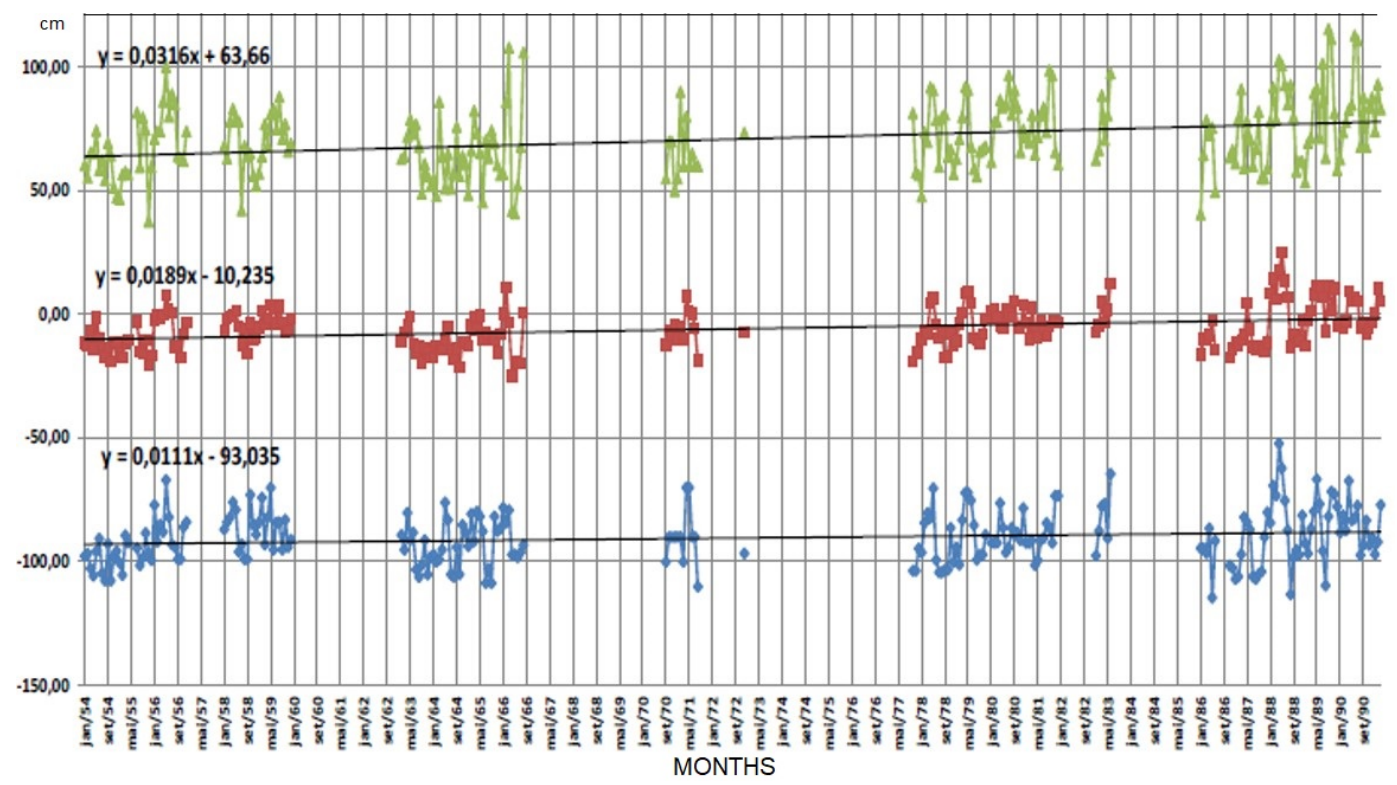

Figure 6. Graph of Ubatuba monthly tidal level variability from 1954 to 1991. Linear trends of MSL (Mean Sea Level), HHW (Highest High Water) and LLW (Lowest Low Water). 


\section{REFERENCES}

Alfredini, P.; Arasaki, E., and Pezzoli, A., 2015. The impact of sea level rise in Santos Port (Brazil) for the next decades. Proceedings of 36th Congress of the International Association of Hydraulic Research (The Hague, The Netherlands), Paper 84810.

Alfredini, P. and Arasaki, E., 2018. Estimation and impacts of sea level rise in Santos Port and adjacent areas (Brazil). TransNav, the International Journal on Marine Navigation and Safety of Sea Transportation, 12, 739-744.

Cartacho, D. L. Análise probabilística chuva-maré para a Bacia do Rio Santo Antônio em Caraguatatuba (SP). São Paulo, 2013. Dissertação (Mestrado apresentado ao Departamento de Engenharia Hidráulica e Sanitária da Escola Politécnica da Universidade de São Paulo).

DEFRA - Department for Environment, Food \& Rural Affairs of the UK Government, 2010. Defra's Climate Change Plan 2010. https://www.gov.uk/government/uploads/system/uploa ds/attachment_data/file/69254/pb13358-climate-changeplan-2010-100324.pdf

FEMAR - Fundação de Estudos do Mar, 2000. Catálogo de Estações Maregráficas Brasileiras. Rio de Janeiro.
Franco, A. S., 2009. Marés: Fundamentos, Análise e Previsão. Niteroi, Diretoria de Hidrografia e Navegação, Niteroi.

IPCC, 2013. Summary for Policymakers. Climate Change 2013: The Physical Science Basis. Contribution of Working Group I to the Fifth Assessment Report of the Intergovernmental Panel on Climate Change. Cambridge University Press, Cambridge, United Kingdom and New York, NY, USA.

Nicholls, R.J.; Hanson, S., Herweijer, C., Patmore, N., Hallegatte, S., Corfee-Morlot, J., Château, J. and MuirWood, R., 2008. Ranking Port Cities with High Exposure and Vulnerability to Climate Extremes: Exposure Estimates. Paris: OECD Publishing, OECD Environment Working Papers 1, 63p. http://dx.doi.org/10.1787/011766488208

PIANC - The World Association for Waterborne Transport Infrastructure, 2014. Countries in Transition (CIT) Coastal Erosion Mitigation Guidelines. Brussels, Belgium: Cooperation Commission (CoCom), PIANC Report 123.

PIANC - The World Association for Waterborne Transport Infrastructure, 2014. Sustainable Ports, A Guide for Port Authorities. Brussels, Belgium: IAPH EnviCom Report Working Group 150, PIANC Report 150.

Rahmstorf, S., 2007. A semi-empirical approach to projecting future sea-level rise. Science, 315, 368-370. 